DOI: http://dx.doi.org/10.33846/ghs6103

\title{
Pengaruh Kebisingan Terhadap Produktivitas Kerja di Mebel Gemba Kecamatan Kairatu Kabupaten Seram Bagian Barat Tahun 2020
}

\author{
Sunik Cahyawati (koresponden) \\ STIKes Maluku Husada; sunikcahyawati87@gmail.com \\ Mega Yuniar Latuamury \\ STIKes Maluku Husada; megayuniar@gmail.com \\ Rifan Fani \\ STIKes Maluku Husada; rifanfani@gmail.com \\ Faradila Rumbia \\ STIKes Maluku Husada; rumbiafaradila@gmail.com
}

\section{ABSTRAK}

Bising industri sudah lama menjadi masalah yang sampai sekarang belum bisa ditanggulangi secara baik sehingga dapat menjadi ancaman serius bagi pendengaran para pekerja, karena dapat menyebabkan kehilangan pendengaran yang sifatnya permanen. Sedangkan bagi pihak industri, bising dapat menyebabkan kerugian ekonomi karena biaya ganti rugi Menurut World Health Organization (WHO) Tahun 2010 adanya alat-alat produksi dan mesin-mesin pada pabrik sebagai penerapan kemajuan teknologi menghasilkan intensitas suara yang dapat menyebabkan kebisingan dan mengganggu kesehatan. Menurut WHO Tahun 1995, diperkirakan hampir 14\% dari total tenaga kerja negara industri terpapar kebisingan lebih dari 90 dBA.tujuan. untuk mengetahui pengaruh kebisingan terhadap produktivitas kerja di mebel gemba kecamatan kairatu kabupaten seram bagian barat tahun2020. Metode, Penelitian ini merupakan penelitian eksperimen degan pendekatan Cross sectional.hasil. Berdasarkan data yang diperoleh ada pengaruh atnara kebisingan dan produktivitas kerja karena diperoleh nilai $p=0,002<0,05$ maka hasil uji dinyatakan signifikan. Artinya ada pengaruh antara kebisingan terhadap Produktivits Di Mebel Gemba. Hasil penelitian ini sejalan degan penelitian sebelumnya dengan judul Analisis Pengaruh Kebisingan Terhadap Tingkat Konsentrasi Kerja Pada Tenaga Kerja, degan hasil $p$ value $=0,000<0,05$ maka hasil uji dinyatakan signifikan. Artinya ada pengaruh kebisingan terhadap tingkat konsentrasi kerja pada tenaga kerja, sehinga bisa mempengaruhi produktivitas kerja.

Kata kunci: sistem pendengaran; kebisingan; produktivitas

\section{PENDAHULUAN}

Bising industri sudah lama menjadi masalah yang sampai sekarang belum bisa ditanggulangi secara baik sehingga dapat menjadi ancaman serius bagi pendengaran para pekerja, karena dapat menyebabkan kehilangan pendengaran yang sifatnya permanen. Sedangkan bagi pihak industri, bising dapat menyebabkan kerugian ekonomi karena biaya ganti rugi Menurut World Health Organization (WHO) Tahun 2010 adanya alat-alat produksi dan mesin-mesin pada pabrik sebagai penerapan kemajuan teknologi menghasilkan intensitas suara yang dapat menyebabkan kebisingan dan mengganggu kesehatan. ${ }^{(1)}$ Menurut WHO Tahun 1995, diperkirakan hampir $14 \%$ dari total tenaga kerja negara industri terpapar kebisingan lebih dari $90 \mathrm{dBA}$. $^{(2)}$

Berdasarkan Peraturan Menteri Tenaga Kerja dan Transmigrasi Nomor 13, 2011, Kebisingan atau Noise Pollution sering disebut sebagai semua suara yang tidak dikehendaki yang bersumber dari alat-alat proses produksi dan/ atau alat-alat kerja yang pada tingkat tertentu dapat menimbulkan gangguan pendengaran. Kebisingan merupakan masalah yang sampai sekarang belum bisa ditanggulangi secara baik karena merupakan salah satu faktor yang diabaikan dari lingkungan kerja sehingga dapat menjadi ancaman serius bagi kesehatan para pekerja. ${ }^{(3)}$

Gangguan pendengaran sering dialami oleh pekerja industry kecil maupun industry besar. Salah satu industry yang pekerjanya sering terpapar bising adalah pekerja mebel. Berdasarkan survey yang dilakukan pada mebel yang ada di desa Waimital rata-rata pekerja sering terpapar bising dari mesin produksi seperti mesin gergaji kayu, mesin bor kayu, mesin serut, mesin ampelas, obeng listrik, komperson untuk pewarnaan dan finishing politer . Berdasarkan observasi para pekerja sering mengalami gangguan akibat bising.misalnya dalam berbicara mereka harus teriak untuk mengalahkan suara mesin. Berdasarkan hasil wawancara yang dilakukan untuk 4 orang pekerja 1 orang menyatakan merasa terganggu dan terkadang nyeri pada telinga dan 1 orang merasa terganggu dalam berkomonikasi karena dalam saat berkomonikasi mereka berbicara degan volume 
yang tinggi/berteriak tetapi tidak ada keluhan nyeri pada telinga. Rata-rata pekerja bekerja selama 8 jam/per hari namun ada juga pekerja yang bekerja kurang dari 8 jam per hari hal ini disebakan karena berbagai faktor salah satunya adalah faktor kebisingan. untuk itu perlu dilakukan penelitian tentang pengaruh kebisingan terhadap produktivitas kerja.

Tujuan penelitian ini adalah untuk mengetahui pengaruh kebisingan terhadap produktivitas kerja di mebel gemba tahun 2020.

\section{METODE}

Penelitian ini merupakan penelitian eksperimen degan pendekatan Cross sectional Penelitian ini berlokasi di Mebel Gemba Kecamatan Kairatu Kabupaten Seram Bagian Barat. Variabel bebas dalam penelitian ini adalah intensitas kebisingan di ukur intensitas pada 5 ruangan yang berbeda. Variabel terikatnya adalah produktivitas tenaga kerja. Penelitian ini akan dimulai pada bulan Juni - Juli Tahun 2020. Populasi adalah keseluruhan obyek yang diteliti. (4) Populasi dalam penelitian ini adalah 40 responden pekerja di mebel Gemba. sampel dalam penelitian inj adalah 40 pekerja mebel teknik sampling yang di gunakan dalam penelitian ini adalah total sampling. Analisis data yang digunakan dalam penelitian ini adalah univariat dan bivariat

\section{HASIL}

\section{Distribusi Responden Berdasarkan Kelompok Umur}

Tabel 1. Distribusi responden berdasarkan kelopok umur di mebel

\begin{tabular}{|l|l|l|}
\hline Umur & $(\mathrm{n})$ & $(\%)$ \\
\hline $18-25$ & 5 & 12.5 \\
\hline $26-35$ & 11 & 27.5 \\
\hline $36-45$ & 11 & 27.5 \\
\hline $46-55$ & 10 & 25.0 \\
\hline $56-65$ & 3 & 7.5 \\
\hline Total & 40 & 100 \\
\hline
\end{tabular}

Dari tabel 1 distribusi responden berdasarkan kelompok umur terbanyak yaitu 26-35 tahun,3645 tahun tahun sebesar $27,5 \%$

\section{Distribusi Responden Berdasarkan Jenis Kelamin}

Tabel 2. Distribusi responden berdasarkan jenis kelamin di mebel

\begin{tabular}{|c|c|c|}
\hline Jenis kelamin & $(\mathrm{n})$ & $(\%)$ \\
\hline Laki-laki & 31 & 77.5 \\
\hline Perempuan & 9 & 22.5 \\
\hline Total & 40 & 100 \\
\hline
\end{tabular}

Dari tabel 2 distribusi responden berdasarkan jenis kelamin terbanyak yaitu laki-laki sebesar $77,5 \%$

\section{Distribusi Responden Berdasarkan Pendidikan}

Tabel 3. Distribusi responden berdasarkan pendidikan di mebel

\begin{tabular}{|c|c|c|}
\hline Pendidikan & $(\mathrm{n})$ & $(\%)$ \\
\hline Tidak sekolah & 3 & 7.5 \\
\hline SD & 11 & 27.5 \\
\hline SMP & 19 & 47.5 \\
\hline SMA & 7 & 17.5 \\
\hline Total & 40 & 100 \\
\hline
\end{tabular}



$47.5 \%$

Dari tabel 3 distribusi responden menurut tingkat pendidikan terbanyak yaitu SMP sebesar

\section{Distribusi Responden Berdasarkan Lama Kerja}

Tabel 4. Distribusi Responden Berdasarkan Lama Kerja di Mebel

\begin{tabular}{|c|c|c|}
\hline Lama kerja & $(\mathrm{n})$ & $(\%)$ \\
\hline$\geq 5$ & 22 & 55.0 \\
\hline$<5$ & 18 & 45.0 \\
\hline Total & 40 & 100 \\
\hline
\end{tabular}
responden.

Distribusi responden menurut lama kerja yang terbesar yaitu $\geq 5$ tahun sebanyak 22

\section{Distribusi Kebisingan}

Tabel 5. Distribusi Responden Berdasarkan kebisingan di Desa Waimita

\begin{tabular}{|c|c|c|}
\hline Kebisingan & $(\mathrm{n})$ & $(\%)$ \\
\hline$\geq 85$ & 24 & 60.0 \\
\hline$<85$ & 16 & 40.0 \\
\hline Total & 40 & 100 \\
\hline
\end{tabular}

Tabel 5 mengabarkan bahwa kebisingan yang terdapat pada pekerja mebel degan nilai pendegaranya lebih $\geq 85$ degan responden 24 orang

\section{Karakteristik Responden Berdasarkan Produktivitas}

Tabel 6. Distribusi responden berdasarkan produktivitas di Desa Waimital

\begin{tabular}{|c|c|c|}
\hline Produktivitas & $(\%)$ & $(\%)$ \\
\hline Tidak produktiv & 25 & 62.5 \\
\hline produktiv & 15 & 37.5 \\
\hline Total & 40 & 100 \\
\hline
\end{tabular}

Tabel 6 mengabarkan bahwa tidak produktivitas yang terdapat pada pekerja mebel yang tertinggi 25 responden

\section{Analisis Bivariat}

Tabel 7. Pengaruh kebisingan terhadap produktivitas kerja di mebel

\begin{tabular}{|c|c|c|r|c|c|c|c|}
\hline & \multicolumn{6}{|c|}{ Produktivitas kerja } & $P$ value \\
\hline Kebisingan & Tidak produktiv & \multicolumn{1}{|c|}{ Produktiv } & \multicolumn{1}{c|}{ jumlah } \\
\hline & $\mathrm{n}$ & $\%$ & $\mathrm{n}$ & $\%$ & $\mathrm{n}$ & $\%$ & \\
\hline Bising & 4 & $16.7 \%$ & 20 & $83.3 \%$ & 24 & 100.0 & 0,002 \\
\hline Tidak bising & 11 & $68.8 \%$ & 5 & $31.2 \%$ & 16 & 100,0 & \\
\hline Total & 15 & 100,0 & 25 & 100,0 & 40 & 100,0 & \\
\hline
\end{tabular}

Berdasarkan tabel 7 di atas dapat dijelaskan sebanyak 24 responden mengalami kebisingan yang berdampak pada produktrivitas kerja berdasarkan statistic hasil uji che squer bahwa nilai $p$ $0,002(<0,05)$ maka dapat disimpulkan bahwa ada hubungan antara kebisingan dengan produktivitas kerja di mebel gemba tahun 2020.

\section{PEMBAHASAN}

Berdasarkan data yang diperoleh ada hubungan atnara kebisingan dan produktivitas kerja karena diperoleh nilai $p=0,002<0,05$ maka hasil uji dinyatakan signifikan. Artinya ada pengaruh antara 
kebisingan terhadap Produktivits Di Mebel Gemba. Kondisi lingkugan kerja yang berada pada mebel gemba Selama 8 jam kerja Ada kariyawan yang merasa tergangu saat berkomonikasi ada juga yang merasa tergangu pada system pendegaran, akibat bising yang terlalu tinggi akirnya mereka istirahat di luar jam kerja yang sudah di tentukan oleh mebel tersebut biasanya 15 menit-20 menit. Kemudian mereka lanjut dengan pekerjannya kembali. Jika ada jam istirahat diluar jam kerja tadi maka bisa mempegaruhi produktivitas kerja pada kariyawan yang berada di mebel gemba.

Berdasarkan data pada tabel 5.7 dari 24 orang dalam lingkungan bising 83,3\%, produktivitas, sebaliknya dari 16 orang dalam lingkungan tidak bising $68,8 \%$ tidak produktiv. Hal ini bisa terjadi karena dalam menghasilkan prodak pada mebel tersebut mengunakan peralatan mesin yang semuanya menibulkan kebisingan. Jadi kebisingan yang timbul/menjadi pengaruh skonsekwensi dari mesin/alat yang di gunakan semakin banyak alat yang di gunakan semakin bising.

Lingkungan kerja yang kurang mendukung dapat menyebabkan kariyawan mengalami stres dan penurunan kesehatan yang dapat berakibat pada berkurangnya konsentrasi dan produktivitas para pekerja. Kebisingan adalah salah satu polusi yang tidak dikehendaki oleh telinga. Jika tingkat kebisingan yang melebihi nilai ambang batas maka dapat menimbulkan masalah yang serius bagi indera pendengaran kita bahkan dapat menyebabkan ketulian atau yang disebut dengan Noise Induced Deafness. ${ }^{(5)}$

Hasil penelitian ini sejalan degan penelitian sebelumnya dengan judul Analisis Pengaruh Kebisingan Terhadap Tingkat Konsentrasi Kerja Pada Tenaga Kerja, degan hasil $p$ value $=0,000$ $<0,05$ maka hasil uji dinyatakan signifikan. Artinya ada pengaruh kebisingan terhadap tingkat konsentrasi kerja pada tenaga kerja, sehinga bisah mempengaruhi produktivitas kerja. ${ }^{(6)}$

Sama halnya dengan penelitian dengan judul Hubungan Antara Intensitas Kebisingan Dengan Tekanan Darah Dan Denyut Nadi Pada Pekerja Industri Mebel Di Desa Leilem. Dengan nilai $p=$ $0,04<0,05$ maka hasil uji dinyatakan signifikan. ${ }^{(7)}$

Sama juga dengan penelitian yang dilakukan oleh Ratih Perwita Sari Pengaruh Intensitas Kebisingan Terhadap Kelelahan Kerja Pada Tenaga Kerja, Dari hasil yang diperoleh $p$ value 0,001 $\leq$ 0,01 maka ada pengaruh intensitas kebisingan dengan kelelahan kerja, sehingga mempegaruhi produktivitas kerja

Sesuai Peraturan Menteri Tenaga Kerja dan Transmigrasi No: PER.13/MEN/X/2011 tentang Nilai Ambang Batas faktor fisika kebisingan ditempat kerja sebesar $85 \mathrm{~dB}$ merupakan nilai yang masih dapat diterima oleh pekerja tanpa mengakibatkan penyakit atau gangguan kesehatan dalam pekerjaan sehari-hari untuk waktu tidak melebihi 8 jam sehari atau 40 jam seminggu, sebaliknya jika melibihi nilai ambang batas maka terdapat ganguan pada indera pendegaran, gangguan fisikologi, sampai pada stres yang menunjukan pada keadaan cepat marah,sakit kepala, gangguan tidur, kehilagan konsentrasi, gangguan konsentrasi antara lawan bicara yang kesemuanya itu akan bermuara pada penurunan performa kerja sehingga akan kehilagan efisiensi dan produktivitas. ${ }^{\left({ }^{(8)}\right.}$

Oleh karena itu, setiap periode perusahaan selalu melakukan pengukuran produktivitas, agar diketahui perubahan nilai produktivitasnya. Hasil pengukuran akan digunakan sebagai bahan evaluasi terhadap proses- proses operasional harian, sehingga kegiatan perusahaan dapat lebih efisien dan efektif. Proses pengukuran produktivitas dalam satu periode dikenal dengan siklus produktivitas, yang terdiri dari Measurement, Evaluation, Planning, Improvement.

\section{KESIMPULAN}

Hasil penelitian menunjukkan bahwa kebisingan berpengaruh terhadap produktivitas kerja di Mebel Gemba Kecamatan Kairatu Kabupaten Seram Bagian Barat.

\section{DAFTAR PUSTAKA}

1. Irwan Powondra, 2015, Studi Deskriptisf Kebisingan Dan Stress Kerja Pada Pekerja Penggiling Padi Di Kecamatan Sawangan, Kabupaten Mangelang Jawah Tengah, Jurusan IImu Kesehatan Masyarakat Fakultas IImu Keolahragahan Unnes.

2. Lintong Fransiska, 2015, Gangguan Pendengaran Akibat Bising, Bagian Fisika: Fakultas Kedokteran Universitas Sam Ratulangi Manado.

3. Rumerung dkk. 2019 Hubungan Antara Intensitas Kebisingan Dengan Tekanan Darah Dan Denyut Nadi Pada Pekerja Industri Mebel Di Desa Leilem

4. Nursalam. (2016).Konsep Dan Penerapan Metodologi Penelitian IImu Keperawatan.Ed 2.Selemba Medika:Jakarta

5. Syarifiddin, Muzir, 2015, Analisis Penentuan Pola Kebisingan Berdasarkan Nilai Ambang Batas (NAB) Pada Power Plant Di PT Arun NGL. Aceh: Fakultas Teknik, Unversitas Malikussaleh. 
6. Nicolas Anugrah Firman, dkk 2016, Faktor-Faktor Yang Berhubungan Degan Gangguan Piskologi Akibat Kebisingan Pada Teknis di Perseroan Terbatas Perusahan Listrik Negara Sector Pembangkit Kendariunit Posia. Fakulitas Kesehatan Masyarakat Universitas Halu Oleo.

7. Rumerung dkk. 2019 Hubungan Antara Intensitas Kebisingan Dengan Tekanan Darah Dan Denyut Nadi Pada Pekerja Industri Mebel Di Desa Leilem

8. Amalia Desi Rizqa, dkk, 201 5, Analisis Pengendalian Kebisingan di Area Bodi Minibus Perusahaan Koroser, Bagian Keslamatan dan Kesehatan Kerja, Fakultas Kesehatan Masyarakat, UNDIP. 